\title{
Syllable Structure in Rumthawi Arabic
}

\author{
Naser N. AlBzour \\ Department of English Language and Literature, Al AlBayt University (AABU), Jordan \\ E-mail: nnnbzour@gmail.com
}

Doi:10.7575/aiac.alls.v.6n.4p.185

URL: http://dx.doi.org/10.7575/aiac.alls.v.6n.4p.185
Received: 08/04/2015

Accepted: 16/06/2015

\begin{abstract}
This paper aims at investigating some phonological aspects of syllable structure in Rumthawi Arabic, a Levantine variety spoken in the northern region of Jordan. It basically sheds light on the OT constraint interaction that determines the surfacing onsets and codas of syllables in this dialect. The scope of this paper is more specifically confined to examining the optimal candidates that surface when the definite article morpheme is prefixed. It thus proves that OT constraints in RA interact in an interestingly distinctive way that triggers divergence and sometimes convergence with other dialects due to the parametrical ranking of these constraints in this dialect unlike some other dialects. It is hoped that this humble endeavor will give insight to many interested researchers to deeply investigate various phonological aspects of this dialect.
\end{abstract}

Keywords: optimality, syllable structure, onset, coda, epenthesis, constraints, faithfulness, markedness

\section{Introduction}

As controversial as the way its name is in multiple variation when articulated as [ər.rəm.thə], [Ir.rəm.thə], [Ir.IIm.thə] and [Ir.rom.thə], Rumthawi dialect is distinctively peculiar. Al-Rumtha, the researchers' beautiful serene hometown, is a major Jordanian city lying in the utmost northern boarder-line region at the corner point of Huran Plains between Jordan and Syria. Approximately, ninety thousand people constitute the population of this agricultural area. Many integrated historical, economic, social and linguistic aspects pour in one crucible that may contribute to marking this Rumthawi dialect as such among other regional dialects. This markedness can be noticeably recognized at various levels: lexical, syntactic, semantic and for sure phonological.

The significance of this paper emanates from the fact that most recent phonological studies tend to label Arabic dialects into broad categories such as Arabic, Egyptian Arabic, Levantine Arabic, Jordanian Arabic ,etc. Broad categories will definitely engender broad generalizations that might be inaccurately construed and construed. Few studies have tackled particularly exclusive dialects in their regional and socio-demographic contexts. Many studies have been conducted in the over-generic mood examining Levantine Arabic, and less generically Abu-Salim's (1982) Palestinian Arabic, let alone what appears to be incognizance of the relationship between such dialects as it is evident in Kager's erroneous remark (1997, 496), "Into the second class ('categorial deletion') fall syncope patterns found in various Arabic dialects (Levantine and Palestinian Arabic syncope and metrical structure are analyzed in an OT framework in Kager 1995)". The claim that 'Levantine and Palestinian Arabic...' ignores the very axiom that Palestinian Arabic is one of the Levantine Arabic varieties in addition to Jordanian, Lebanese and Syrian. This unfortunately reflects that there is a spirit of ad hoc analysis of these dialects either because the authors investigate ad hoc data or because the data have not been authentically attested. However, Irsheid-Kenstowicz's (1984) Bani- Hassan Arabic is one of the first works in phonology that seriously endeavors to explore a specific Jordanian dialect as such, yet it is carried out and implemented in terms of segmental and metrical phonology.

\section{Significance and Scope of the study}

The present study attempts to study the syllable structure and its role in determining syllabification patterns in Rumthawi Arabic (henceforth, RA), with respect to some universal constraints. Theoretically this paper is expected to present tangible evidence in support of the major assumptions whether the syllable is a universally phonological constituent in a phonological theory or not. It is an attempt to elucidate some aspects of the syllable structure as elaborately established by various phonologists who have elicited a plethora of issues pertaining to syllabification constraints such as Maximal Onset Principle and Sonority Hierarchy; phonological changes such as syncope, geminates, epenthesis; in addition to manifesting syllable internal structure and syllable types. However, the scope of this research is technically confined to examining the onset and the coda of the syllable in RA. The focus of the analysis will be, therefore, within a non-linear framework of generative phonology, in general, with particular emphasis on basic relevant assumptions of optimality theory to fathom the rudimentary structure of RA syllables which might consequently diverge or converge at certain levels with previous analyses implemented to other vernacular or Standard Arabic varieties. 


\section{Results and Analysis}

Speech sounds do not normally occur in isolation. Rather, they are put together according to certain constraints (some are language-specific and some are universal) to build up larger units like syllables and words. Words can, therefore, be subdivided into smaller units called syllables. The syllable has for long been taken as a phonological unit (Selkirk 1982, Katamba1989, Roca and Johnson 1999, et al). Such studies have shown that in many languages of the world many phonological features can be properly accounted for by recognizing the syllable as a unit rather than combinations of segments. The syllable is therefore a linguistically significant unit which must have its place in a phonological theory.

There is evidence that the syllable is a universal phonological constituent. First, the most general and explanatory statement of phonotactic constraints in language can be made only by reference to the syllable structure. Selkirk (1982) and Katamba (1989) emphasize that the syllable is the essence of phonological representation, and that it is purely a phonological entity. Second, many phonological generalizations and rules are best stated in terms of the syllable structure, or, put differently, cannot be sufficiently expressed without reference to it . By the same token, the syllable structure plays a pivotal role in the placement of word stress. When stress falls on a syllable, that syllable is referred as being stressed.

Non-linear phonology, on the other hand, looks at the syllable as a hierarchical unit consisting of onset and rhyme constituents. By adopting this approach, it has become more possible for linguists to formulate substantial rules for word stress placement in different languages without resorting to very complicated sequences of segments, even though those languages may have diverse syllable structures. The distinction between heavy and light syllables (i.e. syllable weight) is a fundamental property of syllable constituency in non-linear phonology. In a nutshell, the study in hand investigates the syllable structure of Rumthawi Arabic adopting the non-linear phonology, mainly OT which considers the syllable (rather than segments) as the basic phonological unit.

Traditionally, O'Connor $(1973,200)$ defines the syllable as "a unit containing one and only one vowel either alone or surrounded by consonants in certain numbers and certain arrangements." It is apparent that O'Connor focuses on the distributional, phonotactics description of the syllable. This functional definition is language-specific; that is, it's peculiar to one language but may not apply to another. After the segmental/linear approach (see McCarthy 1979, Kiparsky 1979, Selkirk 1980, et al), the hierarchical analysis of the syllable structure rejected the linear representation of syllables and adopted a hierarchical structure represented by means of a binary tree diagram. The syllable, according to this hypothesis, is divided into two constituents: onset and rhyme. The onset occupies the pre-nuclear position, while the rhyme divides into nucleus and coda.

Abu Salim (1982) examined syllable structure and patterns of Palestinian Arabic within the framework of metrical phonology, yet his analysis seems somehow misleading in some instances because Palestinian Arabic encompasses various dialects that Abu Salim apparently handled as one without specifically delineating the drastic differences that might distinguish these dialects according to differences of their syllable structure. On the other hand, Irsheid and Kenstowitcs (1984) studied Bani Hassan Arabic (BHA), a dialect spoken by a tribe inhabiting the north-eastern regions of Jordan at vicinity with Rumtha, where RA is, nonetheless, distinctively spoken in a manner that undoubtedly marks these two dialects significantly different in terms of their syllable structure and syllabification. Their study, of course, is within the framework of generative phonology not OT, which had not been yet born. The following data from RA and BHA reflect the fact that there is some divergence between these two adjacent dialects. Such divergence is due to prioritizing various violable constraints that each dialect differently stratifies in its hierarchy. Such variation rationalizes different constraint interactions among Arabic varieties as it can be seen in the following data where BHA tends to epenthesize /? I/ syllable initially unlike RA.

(1)

\begin{tabular}{|c|c|c|}
\hline RA & BHA & Gloss \\
\hline səh.bət & ?Is. hə.bət & 'she pulled' \\
\hline Til.Sət & ? IT.lə.Sət & 'she went out' \\
\hline fir.bət & ? If.ru.bət & 'she drank' \\
\hline Sər. $\chi \partial t$ & 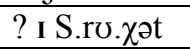 & 'she screamed' \\
\hline Thər.bət & ? IT.hru.bət & 'she hit' \\
\hline Næ.dət & ? I n.di.hət & 'she called' \\
\hline Sirf.ət & ? IS.ru.fət & 'she knew' \\
\hline sək.bət & ? I s.ku.bət & 'she poured' \\
\hline nId.mət & ? In.di.mət & 'she regretted' \\
\hline Til.Sət & ? IT.lə.Sət & 'she went out' \\
\hline
\end{tabular}

The structure of the syllable in Arabic is similar to English Syllable structure in the way that it consists of a nucleus (an obligatory segment either short or long) and rhyme: onset and coda (only the coda is an optional segment). Arabic onset differs from English onset in that it is obligatory and always consists of a single consonant; the coda consists of zero, one, or two consonants . Every vowel in an utterance in Standard Arabic (SA) represents a syllable nucleus. Moreover, syllabic consonants are not found in SA. Thus, the number of syllables in an utterance is identical to the number of vowels (Al-Ani and May 1978: 120). 
3.1 Standard Arabic Syllable Types

Phonologists seem to agree that the following five types of syllable occur in Arabic:

1. CV as in / ka.to.bə / 'he wrote'

2. CVV as in / kaa. to. bə / 'he corresponded'

3. CVC as in / Səm / 'paternal uncle'

4. CVVC as in / sææd / 'prevailed'

5. CVCC as in / ९ərD / 'honor'

With respect to length, the syllable in SA can be divided into the following:

(a) Short syllable : CV

(b) Medium syllables : CVV, CVC

(c) Long syllables : CVVCC, CVVC, CVCC

In terms of open/closed distinction, the syllable in SA can be classified into :

a. Open syllables: $\mathrm{CV}, \mathrm{CVV}$

b. Closed syllables: CVC, CVVC, CVCC, CVVCC

Regarding frequency of occurrence, the first three types (CV, CVV, CVC) occur much more often than do the last three (CVVC, CVCC \& CVVCC); the short open syllable (CV) being the most frequent of all, and CVVCC being the least frequent (Al-Ani and May 1978, 118). As for distribution of syllable types, Al-Ani and May (ibid) argue that the first three patterns (CV, CVV, CVC) occur without restriction, i.e., initially, medially, and finally in an utterance. The last three types, nevertheless, are not freely distributed. CVCC and CVVC, for instance, occur mainly in final position of words and utterances in pause. The CVVCC type occurs exclusively syllable-finally in an utterance in pause form. The six syllable types in SA clearly refers to the fact that SA syllable structure never begins with a vowel, and if it starts with a vowel, the glottal stop $/$ ?/ is consequently epenthesized before that vowel.

\subsection{Syllable Structure in $R A$}

At the phonetic level, there are five basic syllable types in RA. These types are exemplified below. The first five types are used freely in any position within the word, that is, initially medially and finally. The other three types are somehow frequent only in initial position as exemplified below:

Distribution of RA Syllable Types: Word-Initially, Medially and Finally

\begin{tabular}{|c|c|c|c|}
\hline $\begin{array}{l}\text { Syllable } \\
\text { Type }\end{array}$ & Initially & Medially & Finally \\
\hline $\mathrm{CV}$ & /sə .mə/ 'sky' & $\begin{array}{l}\text { /bin.Tə.rId/ } \\
\text { 'to be expelled' }\end{array}$ & $\begin{array}{l}\text { /Tə.rət.to/ } \\
\text { 'I eplelled him' }\end{array}$ \\
\hline $\mathrm{CVV}$ & /bei.tu/ 'his house' & $\begin{array}{l}\text { /ठə.rei.beh/ } \\
\text { 'tax' }\end{array}$ & $\begin{array}{l}\text { /səm.maaU/ } \\
\text { 'he named him' }\end{array}$ \\
\hline $\mathrm{CVC}$ & $\begin{array}{l}\text { /Təm.mən/ } \\
\text { 'she reassured }\end{array}$ & $\begin{array}{l}\text { / Təm.mən.nə / } \\
\text { 'he reassured us' }\end{array}$ & $\begin{array}{l}\text { / ðə.ma:n/ } \\
\text { 'insurance' }\end{array}$ \\
\hline CVCC & $\begin{array}{l}\text { /zomm.nI/ } \\
\text { 'carry me }\end{array}$ & $\begin{array}{l}\text { /ðə.bəht.ta/ } \\
\text { 'I killed her' }\end{array}$ & $\begin{array}{l}\text { /In.hə.bəst/ } \\
\text { 'I was jailed' }\end{array}$ \\
\hline CVVC & $\begin{array}{l}\text { / beit.kv / } \\
\text { 'your house' }\end{array}$ & $\begin{array}{l}\text { /xab.beit.hə/ } \\
\text { 'I hid her' }\end{array}$ & $\begin{array}{l}\text { /səb.beit/ } \\
\text { 'I cursed' }\end{array}$ \\
\hline $\mathrm{CCV}$ & /stə.wa/ 'he became ripe'/ & & \\
\hline $\mathrm{CCVC}$ & /stəw.ћə// 'he felt lonely/like a beast' & & \\
\hline CCVVC & /tylaab.hum/ 'their dogs' & & \\
\hline CCVV & /Slaa.xI/“jerk.(m)’ & & \\
\hline
\end{tabular}

Optimality Theory is supposedly the mainstream trend in phonological theories that may best explain differences among dialects. OT, therefore, accounts for such differences in light of setting pertinent violable constraints. Language-specific rules, within this model, are "attained through the language-specific ranking of the crucially violable constraints, the substance of which is ideally conceived of as universal", (Roca and Johnson 1999, 584-585). The Optimal nominee 'winner' is thus decided primarily in accordance with satisfying the top ranked constraints unlike 'losers', which are accordingly excluded as a result of fatal or more serious violations. Then, the OT basic assumptions can be best understood in a continuous competing relationship between two categories of constraints, namely, Faithfulness and markedness Constraints (Prince and Smolensky,1993). Accordingly, McCarthy (2007b, 266) sums up:

Faithfulness constraints are inherently conservative, requiring the output of the grammar to resemble its input. Because markedness constraints favor some linguistic structures over others, they are often in tension with faithfulness constraints, which resist changes to input structures. This tension is called constraint conflict, and it is resolved in OT by ranking.

McCarthy (Ibid) argues that every syllable in Arabic must have an onset, therefore, [?] is epenthesized whenever 'it is needed to ensure that outcome'. So he correctly, yet in less accurate terms concludes that if Onset dominates the 
antiepenthesis faithfulness constraint (and certain other ranking requirements are met), then candidates that resolve onsetless syllables by epenthesis will be preferred to candidates that preserve them, so /al-wələd/ 'The boy'-> [?alwələd], *[al-wələd]. He, Furthermore, reiterates the following:

The mapping from underlying /ktub/ to surface [uktub] 'write!' in Arabic involves a two-step derivation in rule-based phonology, with vowel epenthesis creating the context that necessitates [?] epenthesis. In OT, on the other hand, the grammar compares candidates that may show the simultaneous effects of two or more epenthesis operations, and [?uktub] is among them. (ibid, 282).

(3)

\begin{tabular}{|l|l|l|l|}
\hline$/$ ktub/ & ONSET & $* \#$ CC & DEP \\
\hline a. ?uktub & & & $* *$ \\
\hline b. ktub & & $* \mathrm{~W}$ & $\mathrm{~L}$ \\
\hline c. uktub & $* \mathrm{~W}$ & & ${ }^{*} \mathrm{~L}$ \\
\hline
\end{tabular}

(McCarthy:282)

McCarthy's analysis in (3) is undubiously neat and elegant, yet it sometimes lacks accuracy to be so generalized to 'Arabic', so which Arabic is in question in this given case. If the answer is Standard Arabic, then that would be incorrect because there are different Standard varieties of Arabic that contradict MacCarthy's winner /?uktub/- at least some different readings of the 'most standard' versions of almost unanimously agreed upon standard Arabics exist in the Holy Qur'an (Muslims' Holy Scripture), where the non-epenthesized version /ktub/ in Warsh Recitation of Standard Arabic is the optimal choice along with the other Qurashi SA/?uktub/.

More intriguingly, RA and Lebanese Arabic which belong to the same Levantine Arabic, lend themselves rather differently to this very constraint- though McCarthy $(2007 \mathrm{~b})$ treats almost all Levantine Arabic varieties under the same broad label 'Levantine'. For instance, the Lebanese optimal choice is /ktoub/ i.e neither initial vowel nor glottal epentheses, but rather with medial diphthonganization. RA, on the contrary, prefers to have alliance with the 'standard' version with epenthesized elements, so the winner is /?ktub/. More interestingly, Lebanese prefers the 'standard' mechanism of SA choice /?alwələd/, although the epenthesized vowel is almost the high front vowel /I/, so the optimal choice is /?Ilwələd/. However, RA shows sheer divergence with the 'standard' choice, so we have the optimal choice /lwələd/ which disprefers epentheses, yet it realizes the sonority profile. These two examples clearly reflect how each dialect can be differently deemed susceptible to these constraints in a disparate manner which, therefore, exemplifies a parametric choice of these dialects based on different hierarchical interaction between these constraints. Examine the following two rules and consequently the accompanying tableaus that can show such an interaction in RA which is similar to SA in (4) and discrepant in (5).

\begin{tabular}{|l|l|}
\hline RA /ktub/ & [?vk.tob] \\
\hline UR & /ktob/ \\
\hline V-epenthesis & ok.tob \\
\hline [?] -epenthesis & ? ok.tob \\
\hline SR & [?vk.tob] \\
\hline
\end{tabular}

\section{(4) Tableau}

\begin{tabular}{|c|l|l|l|}
\hline /ktub/ & ONSET & $* \# \mathrm{CC}$ & DEP \\
\hline a. ?oktub & & & $* *$ \\
\hline b. ktub & & $* \mathrm{~W}$ & $\mathrm{~L}$ \\
\hline c. $v k t u b$ & $* \mathrm{~W}$ & & $* \mathrm{~L}$ \\
\hline
\end{tabular}

Now compare this:

\begin{tabular}{|l|l|}
\hline RA / el-wə.ləd / & {$[$ lwə.ləd] } \\
\hline UR & / el-wə.ləd / \\
\hline V-epenthesis & ----------- \\
\hline$[?]$-epenthesis & ---------- \\
\hline V-deletion & lwə.ləd \\
\hline SR & {$[$ lwə.ləd] } \\
\hline
\end{tabular}

(5)Tableau

\begin{tabular}{|l|l|l|l|}
\hline /el-walad/ & *ONSET & CC & DEP \\
\hline a.lwə.ləd & & $*$ & $*$ \\
\hline b. elwalad & $* \mathrm{~W}$ & $* \mathrm{~W}$ & \\
\hline c. ?alwalad & & & $* \mathrm{~L}$ \\
\hline
\end{tabular}


Syllables universally prefer C- onsets. It is evident, thus far, that RA is no exception, and it lends itself in the same vein to such a universal constraint, so it solves the problem of onsetless syllables by either a process of epenthesis or resyllabification. These two processes anticipate the unique interaction between two constraints; the first bans epenthesis and the second motivates it as it can be formulated below:

a. DEP-IO: Every segment of the output has a correspondent in the input. (McCarthy and Prince, 1995)

b. ONS:Every syllable has an onset. (Prince and Smolensky, 1993)

To substantiate the validity of this argument, sufficient and authentic data should be herein provided. One of the best examples that may manifest such constraint race is the definite article prefix /el/ in RA, which is equivalent to /al/ in SA. This prefix surfaces in two different forms when attached to nouns, thus showing a kind of interaction different from SA and many other vernacular Arabic varieties like Bani Hasan's. The first case represents the so-called the Moon Definite Article, where the consonant /1/ of the definite morpheme prefix /el/ or /al/ is retained and surfaces in the output.

(6) The Moon Definite Article

\begin{tabular}{|c|c|c|c|c|}
\hline /el/al+stem/ & SA & RA & BHA & Glosses \\
\hline Hma:r & ?əl.hı.ma:r & liћ.ma:r & ?ə.ləћ.ma:r & The donkey \\
\hline yra:b & ?əl.yర.ra:b & liy.ra:b & ?ә.әу.ra:b & The raven \\
\hline Ktaab & ?əl. I.taab & lık.taab & ?ə.lək.taab & The book \\
\hline Kra:r & ?əl.KI.ra:r & lik.ra:r & ?ə.laK.ra:r & The young donkeys \\
\hline Hsaab & ?əl.Hı.saab & lift.saab & ?ələH.saab & The account/ Maths/ judgment \\
\hline Hwa:r & ?əl. HI.wa:r & lıH.wa:r & ?ə.ləH.wa:r & The young camel \\
\hline fra:q & ?əl.fi.ra:q & lif.ra:g & ? ə.ləf.ra:g & The departure \\
\hline qma:r & ?əl.qI.ma:r & lig.ma:r & ?ə.ləq.ma:r & The gambling \\
\hline ylaal & ?əl.yı.laal & liy.laal & ?ə.ləy.laal & The harvest \\
\hline yba:r & ?əl.yu.ba:r & liy.ba:r & ?ə.ləy.ba:r & The dust \\
\hline djGa:r & ?əl.djı.Sa:r & lidj.Sa:r & ?ə.lədj.Sa:r & The donkey's bray \\
\hline
\end{tabular}

The data given in this table (6) can delimit the basic phonological features that distinguish the onset in RA from the other two dialects. Examining these words, one can notice the following:

a) All these stems are monosyllabic.

b) All these stems have a CCVVC or CCV:C templates. This means that they are extra-heavy syllables.

c) When the definite prefix is added they all resyllabify.

d) The suffix morpheme has a VC template, and this creates the problem because V-onset syllables are impermissible.

e) The resulting words in SA and BHA consist of three syllables while in RA they consist of two syllables.

f) The structure of the first syllable in SA is subject to glottal stop insertion to avoid V-onset, so VC+CCVC $\rightarrow$ CVC.CV.CVVC. BHA almost operates in the same manner except that the coda consonant re-syllabifies to serve as an onset to the second epenthetic vowel, so VC+ CCVC $\rightarrow$ CV.CVC.CVVC

g) Interestingly, RA syllables behave differently, so the initial vowel elides, thus leaving the consonant $/ 1 /$ to resyllabify with the next syllable which originally has a consonant onset. To avoid another problem , and as a repairing strategy of undesirable output, a vowel is epenthesized medially as a nucleus; the prefix $\mathrm{C}$ serves as an onset; and the first consonant of the first syllable of the stem serves as a coda of the first syllable, so the output is CVC. CVVC or CVC. CV:C thus realizing MAX-ONS constraint as well:

\section{*COPLEX: Syllables have at most one consonant at edge.}

(Archangel and Langendeon.1997)

Hence, we may assume the following constraint hierarchy in RA as represented in the following tableau where the winner candidate is the one that incurs the least fatal violations although it does violate the faithfulness constraint DEPIO. In addition, it seems that ALIGN (R) plays a significant role in determining the optimal candidate in RA; that is why candidate $(\mathrm{c})$ wins over candidate $(\mathrm{d})$.

\section{ALIGN (R): Align root morpheme boundaries with syllable boundaries at both edges; hence, *ONSET $>>$ MAX.ONS-CC $>>$ ALIGN $($ R) $>>$ DEP-IO.}

In RA, furthermore, the markedness constraint SON (Clements, 1990) which stresses the scale of sonority is realized in (c) unlike (a) and (b). Compare the following three tableaus to realize the difference between constraint interaction in RA, on the one hand, and the other two varieties, on the other hand. 


\begin{tabular}{|c|l|l|l|l|}
\hline$/$ el-ktaab/ & ${ }^{2}$ C-ONSET & MAX.ONS-CC & ALIGN (R) & DEP-IO \\
\hline a. el.ktaab & $* !$ & $* *$ & & \\
\hline b. lk.taab & & $* !$ & $*$ & $*$ \\
\hline c. lik.taab & & & & $*$ \\
\hline d. II.ktaab & & $*$ & $*$ & $*$ \\
\hline
\end{tabular}

(6.b.) Tableau SA:

\begin{tabular}{|l|l|l|l|l|}
\hline$/$ al-ktaab/ & $*$ C-ONSET & MAX.ONS-CC & ALIGN (R) & DEP-IO \\
\hline a. al.ktaab & $* !$ & $* *$ & & \\
\hline b. lk.taab & & $* !$ & $* *$ & $*$ \\
\hline c. lık.taab & & & $*$ & $*$ \\
\hline d. . l.ktaab & & $* !$ & $*$ & $*$ \\
\hline e.?al.kı.taab & & & $*$ & $*$ \\
\hline
\end{tabular}

(6.c.) Tableau BHA:

\begin{tabular}{|l|l|l|l|l|}
\hline /al-ktaab/ & $*$ C-ONSET & MAX.ONS-CC & ALIGN (R) & DEP-IO \\
\hline a. al.ktaab & $* !$ & $* !$ & & \\
\hline b. lk.taab & & $* !$ & $* *$ & $*$ \\
\hline c. lik.taab & & & $*$ & $* *$ \\
\hline d. . l..ktaab & & $* !$ & $*$ & $*$ \\
\hline e.?a.lik.taab & & & & $*$ \\
\hline
\end{tabular}

The second case is manifested in the so-called the Sun Definite Article, where the consonant /1/ of the definite morpheme $\mathrm{prefix} / \mathrm{el} / \mathrm{or} / \mathrm{al} /$ is entirely deletes in the surface output.

(7) The Sun Definite Article

\begin{tabular}{|c|c|c|c|c|}
\hline /el/al+stem/ & SA & $\mathrm{RA}$ & BHA & Glosses \\
\hline Sa.məH & әs.sə.maH & ? Is.sə.maH & ?əs.sə.maH & The forgiveness \\
\hline sə.ra:b & ?əs. sə.rab & ? IS. sə.rab & ?əs. sə.rab & The mirage \\
\hline Tə.laaq & ? ә Т.Tə.laaq & ? IT.Tə.laag & ?әТ.Tə.laag & The divorce \\
\hline sə.ma:r & ?as.sa.ma:r & ? Is.sə.ma:r & ?əs.sə.ma:r & The bronwishness \\
\hline zə.raq & ?ə z.zə.raq & ? Iz.zə.raq & ?əz.zə.raq & The blueishness \\
\hline sə.waad & ?əs. sə.wad & ? Is. sə.wad & ?əs. sə.wad & The blackishness \\
\hline də.ma:r & ?əd.da.ma:r & ? Id.də.ma:r & ?əd.də.ma:r & The destruction \\
\hline fə.ra:b & 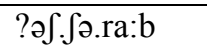 & 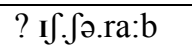 & 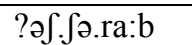 & The juice \\
\hline fə.ra:r & 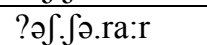 & ? If.forra:r & 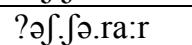 & The sparkles \\
\hline Ju.dja؟ & 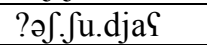 & ? If.Ju.djaS & 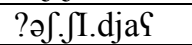 & The brave \\
\hline Sə.fa:r & ?əS.Sə.fa:r & ? IS.Sə.fa:r & ?əS.Sə.fa:r & The yellowishness \\
\hline Sə.da:q & ? s.Sə.da:q & ? Is.Sə.da:q & ?əS.Sə.da:q & The dowry \\
\hline nə.ha:r & ?ən. nə.ha:r & ? In. nə.ha:r & ?ən. nə.ha:r & The day/daylight \\
\hline So.diq & ?ə S.Sə.diq & ? IS.Sə.diq & ?ə S.Sə.diq & The friend \\
\hline
\end{tabular}

Examining these data, one can notice the differences between the behavior of the data in the case of the Moon Definite Article and the Sun Definite Article, which van be summarized in the following issues:
a) All these stems are disyllabic.
b) All these stems have a CV.CVVC or CV.CV:C templates. This means that the first syllable in each is light while the second of each is extra-heavy syllables.
c) When the definite prefix is added they all resyllabify.
d) The suffix morpheme has a VC template, and this creates the problem because V-onset syllables are impermissible.
e) The resulting words in all SA, RA and BHA consist of three syllables with a unified template CV.CV.CVVC or CV.CV.CV:C , so the last syllable of each word is bimoraic and thus it is the accented one.
f) The structure of the first syllable in all these dialects alike is subject to glottal stop insertion to avoid V-onset, so $\mathrm{VC}+\mathrm{CCVC} \rightarrow$ CVC.CV.CVVC/ CV:C.

\section{(7.a.) Tableau RA:}

\begin{tabular}{|l|l|l|l|l|}
\hline /el+Sadiq/ & ONSET & MAX.ONS-CC & ALIGN (R) & DEP-IO \\
\hline a. el.Sə.dig & $*$ & & & \\
\hline b ?eS. ə.dig & $* !$ & & $* *$ & $*$ \\
\hline c. ?e.Sə.dig & & & $*$ & $*$ \\
\hline d.?eS.Sə.diqg & & & & $*$ \\
\hline
\end{tabular}




\section{(7.c) Tableau BHA:}

\begin{tabular}{|l|l|l|l|l|}
\hline /al+Sadiq/ & ONSET & MAX.ONS-CC & ALIGN (R) & DEP-IO \\
\hline a. al.Sə.diq & $*$ & & & \\
\hline b ?aS.ə.diq & $* !$ & & $* *$ & $*$ \\
\hline c. ?a.Sə.diq & & & $*$ & $*$ \\
\hline d.?.S.Sa.diq & & & & $*$ \\
\hline
\end{tabular}

\begin{tabular}{|l|l|l|l|l|}
\hline /al+Sadiq/ & ONSET & MAX.ONS-CC & ALIGN (R) & DEP-IO \\
\hline a. al.Sə.dig & $*$ & & & \\
\hline b ?əS.ə.dig & $* !$ & & $* *$ & $*$ \\
\hline c. ?ə.Sə.dig & & & $*$ & $*$ \\
\hline d.?əS.Sa.dig & & & & $*$ \\
\hline
\end{tabular}

The coda in Arabic at large is not prohibited; on the contrary, it is optionally or rather preferably realized. Examining the data given in (6), one can discern the following interesting phonological processes: in all these dialects the consonant /1/ deletes; hence, the first syllable would surface without coda. Because Arabic prefers syllables with codas, gemination is triggered, so the onset consonant of the second syllable is replicated into two: one to serve as an onset and another to serve as a coda of the preceding syllable. Thus the following tableau shows the interaction between basic onset and simple coda constraints, where the candidate (e)[.?ef.fa .ra:b] wins although it violates some other constraints, but of course less seriously than the other candidates: it violates - COD twice in the second syllable. On the other hand, (c) does violate - COD once, yet it does not win it violates ALIGN which over-ranks - COD.

COD : A syllable must not have a coda. (Prince and Smolensky.1993)

(8.a.) Tableau RA:

\begin{tabular}{|c|c|c|c|c|}
\hline$/$ el+fə.rə:b / & *ONSET & ALIGN (R) & $-\mathrm{COD}$ & DEP-IO \\
\hline a. el.fə.ra:b & $* !$ & & ** & \\
\hline b.? If.ə .ra:b & $* !$ & $*$ & ** & $*$ \\
\hline c. ? I. $\int \partial . \mathbf{r a}: \mathbf{b}$ & & $*$ & * & * \\
\hline d. ? If.for.a:b & $* !$ & & $* * *$ & $*$ \\
\hline e.? If.fə.ra:b & & & $* *$ & $*$ \\
\hline
\end{tabular}

(8.b.) Tableau SA:

\begin{tabular}{|c|c|c|c|c|}
\hline$/ a \mathbf{a}+\int \partial \cdot \mathbf{r a}: \mathbf{b} /$ & *ONSET & ALIGN (R) & -COD & DEP-IO \\
\hline a. əl.fə.ra:b & $* !$ & & ** & \\
\hline b.?əJ.ə .ra:b & $* !$ & * & *** & * \\
\hline 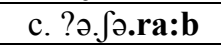 & & * & * & * \\
\hline 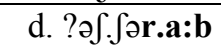 & $* !$ & & $* * *$ & * \\
\hline 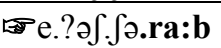 & & & ** & * \\
\hline
\end{tabular}

(8.c.) Tableau BHA:

\begin{tabular}{|c|c|c|c|c|}
\hline$/ \mathrm{al}+\int \ni \cdot \mathbf{r a}: \mathbf{b} /$ & *ONSET & ALIGN (R) & $-\mathrm{COD}$ & DEP-IO \\
\hline a. al.fə.ra:b & $* !$ & & *** & \\
\hline b.?əҐ.ə .ra:b & $* !$ & * & ** & $*$ \\
\hline 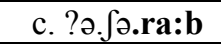 & & * & * & * \\
\hline 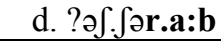 & $* !$ & & $* * *$ & $*$ \\
\hline 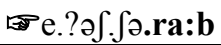 & & & ** & * \\
\hline
\end{tabular}

We have, thus far examined the data on The Moon Definite Article in (6) and The Sun Definite Article in (7) in isolation i.e. the definite article prefixed to the stem. Now, what will happen if we study these data in more interacting environments i.e. when another morpheme precedes the definite article morpheme with the original stem? Would we have a similar constraint interaction in RA as well as the other two varieties, or would we expect different interaction to emerge, and thus new forms to surface?

\section{(9) Morpheme+ The Moon Definite Article+ Morpheme}

\begin{tabular}{|c|c|c|c|c|}
\hline$/$ stem+el/al+stem/ & SA & RA & BHA & Glosses \\
\hline Sawt+el+Hma:r & Saw.tul.ћı.ma:r & Sawt.liћ.ma:r & Saw.ta.lah.ma:r & sound of the donkey \\
\hline Sout + el+yra:b & Sou.tul.yu.ra:b & Sawt.lIy.ra:b & Saw.ta.lay.ra:b & Sound of the raven \\
\hline loun+el+Ktaab & lou.nul.kı.taab & lawn.lık.taab & law.na.lak.taab & color of the book \\
\hline
\end{tabular}




\begin{tabular}{|c|c|c|c|c|}
\hline sbaaq+el+Kra:r & sI.baa.qul.Kı.ra:r & sl.ba:g.lık.ra:r & sI.baa.ga.laK.ra:r & $\begin{array}{l}\text { Race of the young } \\
\text { donkeys }\end{array}$ \\
\hline yawm+el+Hsaab & yaw.mul.Hı.saab & youm.lıH.saab & you.ma.laH.saab & The day of judgment \\
\hline laHm+el+Hwa:r & laH.mul. Hı.wa:r & la.HIm. lıH.wa:r & laH.ma.laH.wa:r & $\begin{array}{l}\text { Meat of the young } \\
\text { camel }\end{array}$ \\
\hline yawm+el+fra:q & yaw.mul.fi.ra:q & yaum.lıf.ra:g & yaw.ma.laf.ra:g & The day of departure \\
\hline laSb+el+qma:r & la.SI.bul.qI.ma:r & II.SIb. IIg.ma:r & IIS.ba.lıq.ma:r & The gambling game \\
\hline sInin+el+ylaal & sI.ni.nul.yı.laal & sI.nin.lıy.laal & sI.ni.n a.lIy.laal & The harvest years \\
\hline Hab.bat+el+yba:r & Hab.ba.tul.yu.ba:r & Hab.bat.lıy.ba:r & Hab.ba.ta.lay.ba:r & The dust grains \\
\hline Sawt+el+djSa:r & Saw.tul.djı.\{a:r & Sawt.lıdj.Sa:r & Saw.ta.ladj.Ya:r & The donkey's bray \\
\hline
\end{tabular}

a) All these stems preceding the definite article morpheme are monosyllabic or disyllabic. What is significant about them is the fact that the adjacent syllables preceding the article are all closed syllables.

b) These adjacent syllables, therefore, have a final C or CC. This creates the difference between RA and other dialects.

c) Hence, when the these stems precede the definite prefix in SA and BHA, they all resyllabify, so the coda of the preceding syllable serves as an onset to the definite article syllable which has required an epenthetic glottal stop in (10) to satisfy the ONS constraint.

d) This issue in RA is solved in the same manner it has been solved in (10), so the definite article /el/ deletes the /e/ and the /1/ serves as a new onset to the following syllable. However, the preceding syllable in the stem preceding the definite article does not interact with it unlike SA and BHA, so the resulting syllable structure is $\mathrm{CVC}+\mathrm{CVC}+\mathrm{CVVC} / \mathrm{CV}: \mathrm{C}$

e) The resulting phrase in SA and BHA consists of the preceding stem ( whether it is one or two syllables) followed by three syllables: (stem CV) $+\mathrm{CVC}+\mathrm{CV}$.CVVC/ CV:C so the preceding closed syllable becomes an open syllable.

\section{(9.a.) Tableau RA:}

\begin{tabular}{|c|l|l|l|l|}
\hline yawm+el+fra:g/ & *ONSET & MAX.ONS-CC & ALIGN (R) & DEP-IO \\
\hline a. yau.mlıf.ra:g & & $* !$ & $*$ & $*$ \\
\hline b. yaum.l.fra:g & & $* !$ & $*$ & $*$ \\
\hline c. yau.mlıf.ra:g & & $* !$ & $*$ & $*$ \\
\hline d. yaum.lıf.ra:g & & & $*$ & $*$ \\
\hline
\end{tabular}

\section{(9.b.) Tableau BHA:}

\begin{tabular}{|l|l|l|l|l|}
\hline$/$ el-ktaab/ & $*$ ONSET & MAX.ONS-CC & ALIGN (R) & DEP-IO \\
\hline a. yau.mal.If.ra:g & $* !$ & $* *$ & $*$ & $*$ \\
\hline b. yau.mlIf.ra:g & & $* !$ & $*$ & $*$ \\
\hline c. yaw.ma.laf.ra:g & & & & $*$ \\
\hline d. yaum.lIf.ra:g & & & $*$ & $*$ \\
\hline
\end{tabular}

(10) Morpheme + The Sun Definite Article + Morpheme

\begin{tabular}{|c|c|c|c|c|}
\hline$/$ stem+el/al+stem/ & SA & RA & BHA & Glosses \\
\hline Talab+el+sa.maH & Ta.la.bus.sa.maH & Ta.la.bıs.sa.maH & Ta.la.bas.sa.maH & Ask for the forgiveness \\
\hline miel+el+sa.ra:b & mie.lus.sa.rab & mi.eI.lıs.sa.ra:b & mie.las.sa.ra:b & Like the mirage \\
\hline waraq+el+Ta.laaq & wa.ra.quT.Ta.laaq & wa.ra.qIT.Ta.laag & wa.ra.qaT.Ta.laag & Documents of the divorce \\
\hline lawn+el+sa.ma:r & law.nus.sa.ma:r & law.nis.sa.ma:r & law.nas.sa.ma:r & The bronwishness color \\
\hline lawn+el+za.ra:q & law.nuz.za.ra:q & law.nIz.za.ra:g & Law.naz.za.ra:g & The blueishness color \\
\hline lawn+el+sa.waad & law.nus. sa.wad & law.nis. sa.wad & law.nas. sa.wad & The blackishness color \\
\hline sinin+el+da.ma:r & si.ni.nud.da.ma:r & sI.ni.nId.da.ma:r & sI.ni.nad.da.ma:r & Years of the destruction \\
\hline taSm+el+ fa.ra:b & TaS.muf.ja.ra:b & 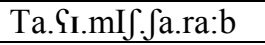 & TaS mas.ja.ra:b & The flavor of juice \\
\hline miøl+el+fa.ra:r & miө.luf.ja.ra:r & mI.eI.lif.fa.ra:r & miө.laf.ja.ra:r & Like the sparkles \\
\hline umm+el+fu.djaS & um.muf.fu.djas & Um.mIS.Ju.djas & 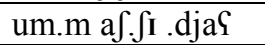 & Mother of the brave \\
\hline lawn+el+Sa.fa:r & law.nuS.Sa.fa:r & law.niS.Sa.fa:r & law.n aS.Sa.fa:r & The yellowishness color \\
\hline waraq+el+Sa.da:q & wa.ra.qus.Sa.da:q & wa.ra.gIs.Sa.da:q & wa.ra.gas.Sa.da:q & Documents of the dowry \\
\hline waqt+el+na.ha:r & waq.tun. na.ha:r & wa.gı.tı n. na.ha:r & wag.tan. na.ha:r & Time of the day/daylight \\
\hline raaH +el+Sa.diq & raa.HaS.Sa.diq & raa.HIS.Sa.diq & raa.HaS.Sa.diq & The friend went away \\
\hline
\end{tabular}

a) Again, all these stems preceding the definite article morpheme are monosyllabic or disyllabic and what matters is the fact that the adjacent syllables preceding the article are all closed syllables with a final C or CC.

b) Hence, when the these stems precede the definite prefix in RA,SA and BHA, they all resyllabify, so the coda of the preceding syllable serves as an onset to the definite article syllable which has required an epenthetic 
glottal stop /?/in (10) to satisfy the ONS constraint; the resulting geminate still behaves in the same was it does in(16) i.e. branching into an onset of the original syllable and a coda of the previous syllable

c) The resulting phrase in SA and BHA consists of the preceding stem (whether it is one or two syllables) followed by three syllables: (stem $\underline{\mathrm{CV}})+\mathrm{CVC}+\mathrm{CV}$. CVVC/ $\mathrm{CV}$ :C so the preceding closed syllable becomes an open syllable.

\section{(10.a.) Tableau RA:}

\begin{tabular}{|c|c|c|c|c|}
\hline$/ \mathbf{m I} \mathbf{I e l + e l + s ə . r a : b /}$ & *ONSET & ALIGN (R) & $-\mathrm{COD}$ & DEP-IO \\
\hline a. mI.eIl. Is.sə.ra:b & $* !$ & & $* * *$ & * \\
\hline b.. mIө.l Is. ə.ra:b & $* !$ & * & $* * *$ & * \\
\hline c. mI.eI. IIs.sə.ra:b & & $*$ & $* *$ & $*$ \\
\hline d.mIө. Il. Is.sə.ra:b & $* ! * !$ & & $* * *$ & * \\
\hline e.mI.øIl.? Is.sə.ra:b & & * & $* * *$ & $* * *$ \\
\hline
\end{tabular}

(10.b.) Tableau RA:

\begin{tabular}{|c|c|c|c|c|}
\hline /mIӨI+el+sə.ra:b/ & *ONSET & ALIGN (R) & $-\mathrm{COD}$ & DEP-IO \\
\hline a. mI.өIl.Iə.sa.ra:b & $* !$ & & $* * *$ & $*$ \\
\hline b.. mIӨ.l Is. ə.ra:b & $* !$ & $*$ & $* * *$ & $*$ \\
\hline Fc. mIө. las.sə.ra:b & & $* *$ & $* * *$ & $*$ \\
\hline d.mIӨ. Il. IS.sə.ra:b & $* ! * !$ & & $* * *$ & $*$ \\
\hline e.mI.ӨIl. ? Is.sə.ra:b & & $*$ & $* * *$ & $* *$ \\
\hline
\end{tabular}

\section{Conclusion}

In conclusion, Arabic varieties show considerable phonological differences among them at various levels. These differences can be best described and interpreted in terms of what each variety may optimally opt for while preferring a particular candidate over others in accordance with the different ranking of such violable constraints that each variety has in its constraint hierarchy. RA is not an exception since its syllable structure proves to behave sometimes in a similar way, and oftentimes in a different way to syllables in SA and other dialects. These differences logically result in deletion, insertion and assimilation in various forms. This study is the first research that handles the phonological structure within any generative approach, let alone OT. Therefore, it is evident that much research is still recommended in this rich and virgin area of variation and language varieties. This is a modest attempt that might trigger many other research to follow.

\section{References}

Abu-Salim, I. M. (1982). A Reanalysis of some aspects of Arabic phonology: A metrical approach. Doctoral Dissertation. Urbana, IL: University of Illinois.

AL-Ani, Salman \& Darlene R. MAY. (1973): The phonological structure of the syllable in Arabic. American Journal of Arabic Studies, 1. 113-125.

Archangeli, D. and D. Terence Langendoen. (1997). Optimality theory: An overview. Blackwell Publishing.

Clements, G. N \& Elizabeth V. Humes. (1995). The internal organization of speech sounds. In Goldsmith, John A. (Ed.), The hand Book of phonology theory. Blackwell Publishing. 245-306.

Hayes, Bruce. (1995). Metrical stress theory: Principles and case studies. Chicago, IL: University of Chicago Press.

Irshid, O. (1984). The phonology of Bani Hasan Arabic. Unpublished Doctoral Dissertation, University of Illinois at Urbana-Champaign.

Irshied, Omar, \& Michael Kenstowicz. (1984). Some phonological rules of Bani-Hassan Arabic. Studies in the Linguistic Sciences. 14 (1),109-48.

Kager, René (1997). Rhythmic vowel deletion in optimality theory, In Roca, Iggy (Ed.), Derivations and constraints in phonology (463-499). Oxford: Oxford University Press.

Kager, René. (1999). Optimality theory. Cambridge, UK: Cambridge University Press.

Katamba, F. (1989). An introduction to phonology. London: Longman

Kenstowicz, M. (1999). Phonology in generative grammar. Blackwell Cambridge MA \& Oxford UK.

Kiprasky, Paul (2003). Syllables and moras in Arabic. in Caroline Fery \& Ruben Van De Vijver (Eds.). The Syllable in Optimality Theory (147-83). Cambridge: Cambridge University Press.

McCarthy, J. (1979). On stress and syllabification. Linguistic Inquiry. 17. 207-63.

McCarthy, J. \& A. Prince (1995). Faithfulness and reduplicative identity. Occasional Papers in Linguistics 18: Papers in Optimality Theory. [ROA \#60]. University of Massachusetts. 
McCarthy, J. (2007.a). What is Optimality Theory? Language and Linguistics Compass 1/4: 260-291.

McCarthy, J. (2007. b). Hidden generalizations, phonological opacity in optimality theory. Equinox Publishing.

O'Conor J. D.(1973). Phonetic drill reader. CUP.

Prince, A. \& P. Smolensky. (1993). Optimality Theory: Constraint interaction in generative grammar. RUCCS-TR-2. ROA-537.

Roca, Iggy (Ed.), (1997). Derivations and constraints in phonology. Oxford, UK: Oxford University Press.

Roca, Iggy. and W. Johnson. (1999). Course in phonology. Oxford: Blackwell. 